Article

\title{
Properties of an Antimicrobial Molecule Produced by an Escherichia coli Champion
}

\author{
Sarah-Jo Paquette ${ }^{1,2}$ and Tim Reuter $1, *$ (1) \\ 1 Alberta Agriculture and Forestry, \#100-5401 1st Ave. South, Lethbridge, AB T1J 4V6, Canada; \\ sarahjo.paquette@uleth.ca \\ 2 Department of Biological Sciences, University of Lethbridge, 4401 University Drive West, Lethbridge, \\ AB T1J 4V6, Canada \\ * Correspondence: tim.reuter@gov.ab.ca
}

Received: 24 October 2019; Accepted: 18 December 2019; Published: 21 December 2019

\begin{abstract}
Over recent decades, the number and frequency of severe pathogen infections have been increasing. Pathogen mitigation strategies in human medicine or in livestock operations are vital to combat emerging arsenals of bacterial virulence and defense mechanisms. Since the emergence of antimicrobial resistance, the competitive nature of bacteria has been considered for the potential treatment or mitigation of pathogens. Previously, we identified a strong E. coli competitor with probiotic properties producing a diffusible antimicrobial molecule(s) that inhibited the growth of Shiga toxin-producing E. coli (STEC). Our current objective was to isolate and examine the properties of this antimicrobial molecule(s). Molecules were isolated by filter sterilization after $12 \mathrm{~h}$ incubation, and bacterial inhibition was compared to relevant controls. Isolated antimicrobial molecule(s) and controls were subjected to temperature, $\mathrm{pH}$, or protease digestion treatments. Changes in inhibition properties were evaluated by comparing the incremental cell growth in the presence of treated and untreated antimicrobial molecule(s). No treatment affected the antimicrobial molecule(s) properties of STEC inhibition, suggesting that at least one molecule produced is an efficacious microcin. The molecule persistence to physiochemical and enzymatic treatments could open a wide window to technical industry-scale applications.
\end{abstract}

Keywords: E. coli; Shiga toxin; inhibition; heat resistance; $\mathrm{pH}$ resistance; enzyme resistance; microcins; antimicrobial molecule

\section{Introduction}

At a certain point in time, humans triggered an evolutionary Big Bang by shaping a new microbial multiverse. Ancestral humans were "hunter-gatherers", living in small nomadic communities foraging for food. Later those communities transitioned to settle permanently in one place, cultivating food and resources. This was the origin of forming areas with dense populations of humans and livestock $[1,2]$. Simultaneously, microbial communities adapted, competed, evolved, and proliferated within those close interactions across agriculture and humans alike. Commensal or virulent Escherichia coli were some of the species among them. The emergence of lethal diseases (e.g., as early as pandemic reports of the Justinian Plague or Black Death) carried by host-adapted pathogens could only be sustained in areas of dense human populace [2]. These environments are also prime spaces to foster bacterial competition for the existence, often coined as the "survival of the fittest" [3-6].

Competition can be categorized as exploitative or interference-based [7]. Exploitative interactions are those where one bacterium is using nutrients more efficiently, effectively starving a competitor. However, exploiter champions can be out-competed by a weaker exploiter using interference competition. Interference competition is based on the production of antagonistic factors that eliminate 
competitors using contact-dependent (growth inhibition and Type VI secretion systems), or contact independent (bacteriocins and other diffusibles, such as antibiotics) means [3,8].

Bacteriocins are molecules (proteins and peptides) produced by both Gram-positive and Gram-negative bacteria [9] and are most often inhibitory to close relatives only [10,11]. However, some Gram-positive bacteriocins have been shown to combat Gram-negative bacteria [12]. Gram-negative bacteriocins have been studied and identified in E. coli and are coined colicins and microcins [13]. Colicins are high-molecular-mass (30-80 kDa) proteins [12] and tightly controlled by the bacterial SOS system $[4,14]$. In contrast, microcins, peptides with molecular masses below $10 \mathrm{kDa}$, are protease and temperature resistant and are reported to resist $\mathrm{pH}$ extremes [12,15]. These characteristics are often associated with bacteriocins of lactic acid bacteria [12].

Bacteriocins are being considered as potential agents to replace antibiotics and have been suggested for use in humans and in livestock as a method to mitigate pathogens [16]. Bacteriocins are considered "agents of competition" [10] and represent a microbial strategy to out-compete their rivals $[4,12]$. Bacteriocins are unique compared to traditional antibiotics, as they harbor a restricted killing spectrum, targeting specific bacteria or species $[10,16]$. The targeted killing of specific bacteria makes producers of these bacteriocins an ideal probiotic. In fact, discovered 100 years ago, Mutaflor ${ }^{\circledR}$ is a commercially available probiotic that contains the strain $E$. coli Nissle which produces two microcins, which are thought to be crucial in the ability of this strain to antagonize E. coli and Salmonella pathogens [17-19].

Among bacterial pathogens, Shiga toxin-producing E. coli (STEC) produces a potent toxin (Shiga toxin), which, in conjunction with other factors, causes severe, often foodborne infections in humans [20,21]. Various mitigation strategies for this pathogen have been considered, including vaccines [22], direct-fed microbials [23], and tannins [24], but none have consistent efficacy. Another mitigation strategy being considered to control STEC is using probiotic bacteria to competitively eliminate the pathogens [25], as demonstrated by the effective use of E. coli Nissle to alleviate intestinal infections in humans [17]. Likewise, a colicin-producing E. coli isolated from sheep fecal samples was shown to inhibit the STEC O157:H7 [25].

In a previous study in our laboratory, we demonstrated that various E. coli strains isolated from beef cattle feces produce diffusible molecules capable of affecting competitor growth when separated by a 4 to $10 \mathrm{~mm}$ barrier of agarose [26]. However, the strength of these molecules varied among strains, which led to the identification of a strong competitive non-pathogenic E. coli champion that produces a diffusible molecule(s) capable of out-competing 31 different $E$. coli strains including STEC O26, O111 and $\mathrm{O} 157$ [26].

The objective of this project is to characterize further the diffusible molecule(s) produced by this $E$. coli champion, while investigating the physicochemical and biological properties of the molecule as well as its antimicrobial potential.

\section{Materials and Methods}

\subsection{Bacterial Strains: Cultures, Media and Culture Conditions}

Both E. coli strains used in this study, O157A and O103F, were described previously [26]. Briefly, E. coli strains were streaked from glycerol stocks onto MacConkey Agar (MAC, BD, Sparks, NV, USA). Plates were incubated overnight $(16-18 \mathrm{~h})$ at $37^{\circ} \mathrm{C}$. A single colony was selected from each plate and inoculated into E. coli broth (EC, EMD Millipore, Etobicoke, ON, Canada) and incubated overnight at $37^{\circ} \mathrm{C}$ with shaking at $150 \mathrm{rpm}$. Overnight cultures of O157A (STEC) and O103F (no detected virulence genes) were diluted to an optical density (OD) of 0.1 measured at a wavelength of $600 \mathrm{~nm}$ in fresh EC and grown for $3 \mathrm{~h}$. The $3 \mathrm{~h}$ culture was then used as inoculation for the treatments.

\subsection{Molecule Isolation Assay}

Molecule isolation assay was adapted from Kulp and Kuehn, 2010 [27] by following the isolation protocol for natural outer membrane vesicles up to and including step 2. O103F molecule is the cell-free 
supernatant collected after $12 \mathrm{~h}$ of growth of O103F in EC, containing AntiMicrobial Molecule(s) and will subsequently be referred to as AMMO. O157A molecule is the cell-free supernatant collected after $12 \mathrm{~h}$ growth of O157A in EC and will be subsequently referred to as SPENT. After isolation, AMMO and SPENT underwent various treatments.

Both E. coli (O103F and O157A) cultures were grown individually for $12 \mathrm{~h}$ and centrifuged $(10,000 \times$ $g$ ) for $10 \mathrm{~min}$ to prepare the supernatant (Figure 1). The supernatant was then filter-sterilized using a $0.22 \mu \mathrm{m}$ filter (Pall Life Sciences, Ann Arbor, MI, USA) to remove all bacterial cells. The O103F supernatant (AMMO) was added to fresh EC to test the growth of O157A cells during the inhibition assay. Each experiment had a complete set of four controls to measure the effect of AMMO. The first control, O157A, was diluted to a starting OD of 0.1 in a final volume of $5 \mathrm{~mL}$ of fresh EC to demonstrate regular/healthy growth of E. coli O157A in fresh media. The second control, O157A, was diluted to a starting of OD 0.1 in a total of $5 \mathrm{~mL}$ (3.75 mL SPENT and $1.25 \mathrm{~mL}$ culture and fresh EC) to take into account the effect of depletion of nutrients and metabolic end products in the isolated supernatants on O157A growth. The third and fourth controls, $3.75 \mathrm{~mL}$ of the supernatants (AMMO or SPENT), were each individually added to $1.25 \mathrm{~mL}$ fresh EC to ensure that filter-sterilization was successful, and all live cells were removed from the supernatants (AMMO and SPENT).
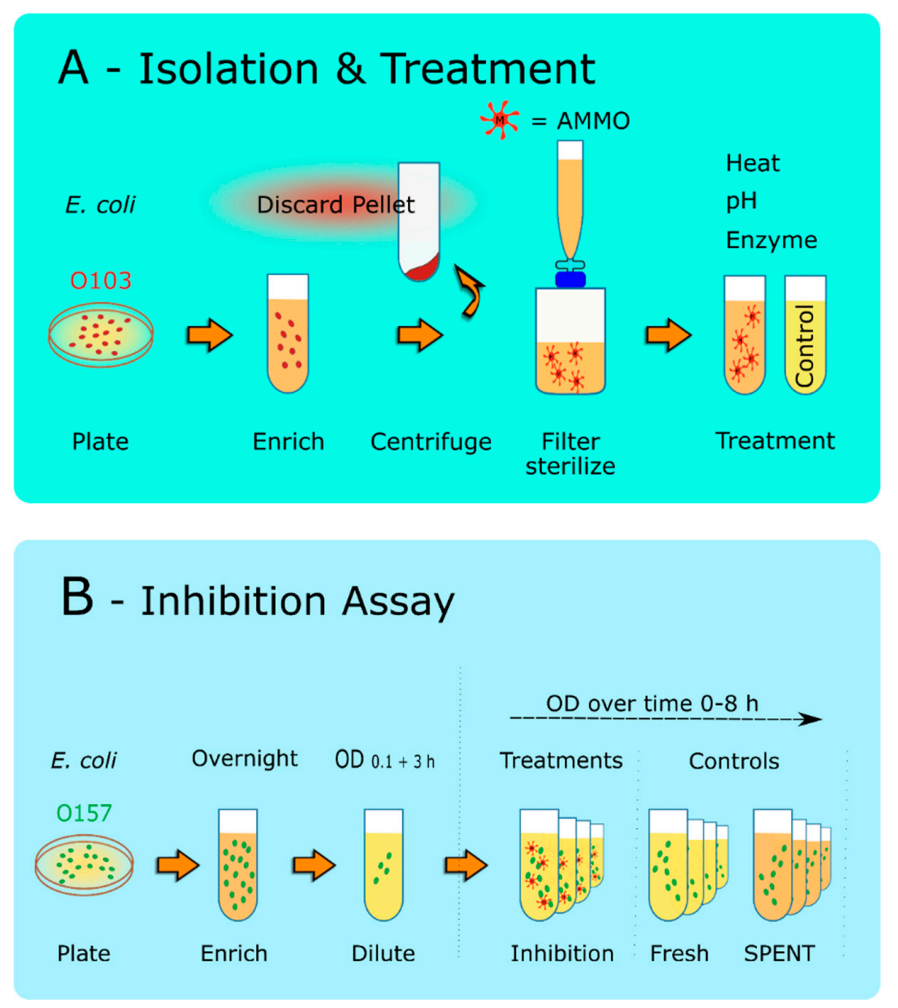

Figure 1. Schematic of the Molecule Isolation Protocol and Inhibition Assay. (A): Isolation and Treatment. E. coli O103F was grown overnight on a MacConkey Agar plate, and a single colony was grown in EC for $12 \mathrm{~h}$. Cells were pelleted at $10,000 \times g$ for $10 \mathrm{~min}$. The cell pellet was discarded, and the supernatant was filter-sterilized using a $0.22 \mu \mathrm{m}$ filter. The sterilized supernatant was then treated to examine, heat, $\mathrm{pH}$, or protease digestion. Note: SPENT was also prepared using the same protocol. (B): Inhibition Assay. O157A was grown overnight for $12 \mathrm{~h}$ in EC. The cells were then diluted to an $\mathrm{OD}_{600 \mathrm{~nm}}$ of 0.1 and grown for $3 \mathrm{~h}$. This culture was then used to inoculate the AMMO and the controls. $\mathrm{OD}_{600 \mathrm{~nm}}$ measurements were taken at $0,2,4,6$, and $8 \mathrm{~h}$. Note: (1) O103F was also prepared using the same protocol when utilized in the experiment. (2) AMMO is the cell-free supernatant collected after $12 \mathrm{~h}$ E. coli O103F growth. SPENT is the cell-free supernatant collected after $12 \mathrm{~h} \mathrm{E}$. coli O157A growth. 


\subsubsection{Isolation Confirmation}

A culture of either O157A or O103F was diluted to a starting OD of 0.1 in a final volume of $5 \mathrm{~mL}$ ( $3.75 \mathrm{~mL}$ of AMMO or SPENT and $1.25 \mathrm{~mL}$ culture and fresh EC). A second control was prepared with O157A or O103F diluted into fresh EC. Subsequently, all cell preparations were incubated at $37^{\circ} \mathrm{C}$ at $150 \mathrm{rpm}$ for $24 \mathrm{~h}$. OD measurements were taken at $0,2,4,6,8$, and $24 \mathrm{~h}$ to extrapolate cell densities using an initially determined strain-specific growth curve data (slope equation: O157A $\rightarrow \mathrm{y}=-6 \times 10^{6}$ $\times 2+4 \times 10^{7} \times-2 \times 10^{6}$ and O103F $\left.\rightarrow y=-2 \times 10^{7} \times 2+7 \times 10^{7} \times-3 \times 10^{6}\right)$.

The growth curve data were analyzed by comparing strain-specific OD values versus CFU plate counts in parallel at the time point $0,2,4,6,8$, and $24 \mathrm{~h}$ (data not shown). All experiments with AMMO and SPENT supernatants were conducted likewise, following the treatments as described below. All experiments were replicated on alternate days with fresh cultures, AMMO, and SPENT.

\subsection{2. $\mathrm{pH}$ Treatment}

To examine the effect of $\mathrm{pH}$ on $\mathrm{AMMO}$, hydrochloric acid $(\mathrm{HCl})$ or sodium hydroxide $(\mathrm{NaOH})$ was added to the supernatants containing the isolated AMMO or SPENT to lower or increase the $\mathrm{pH}$ of the solutions to 3 or 11, respectively. The supernatants were then incubated at either $\mathrm{pH}$ for $3 \mathrm{~h}$. After the incubation, the supernatants (AMMO and SPENT) $\mathrm{pH}$ were neutralized to the $\mathrm{pH}$ pre-treatment by titrating either $\mathrm{HCl}$ or $\mathrm{NaOH}$ solutions and subsequently used for the inhibition assay (Figure 1B).

\subsubsection{Autoclave Treatment}

To examine the effect of heat and pressure treatment, the prepared AMMO and SPENT supernatants were autoclaved for $20 \mathrm{~min}$ at $121^{\circ} \mathrm{C}$ and $18 \mathrm{psi}$. After cooling to room temperature, the supernatants were subsequently used for the inhibition assay (Figure 1B).

\subsubsection{Trypsin Treatment}

To examine the effect of trypsin (Calbiochem, La Jolla, CA, USA) digestion, $5 \mu \mathrm{L}$ of a prepared trypsin solution $(7.5$ units $/ \mu \mathrm{L})$ was added to $20 \mathrm{~mL}$ of the prepared AMMO and SPENT supernatants and incubated for $3 \mathrm{~h}$ at $37^{\circ} \mathrm{C}$. After the incubation, trypsin digestion was stopped by heating the mixture for $10 \mathrm{~min}$ at $95^{\circ} \mathrm{C}$. After cooling to room temperature, AMMO, and SPENT supernatants were used for the inhibition assay (Figure 1B).

\subsubsection{Chymotrypsin Treatment}

To examine the effect of chymotrypsin (Sigma-Aldrich, Oakville, ON, Canada) digestion, $4 \mu \mathrm{L}, \mathrm{n}$ or $40 \mu \mathrm{L}(1 \mathrm{unit} / \mu \mathrm{L})$ of prepared chymotrypsin solution was added to $20 \mathrm{~mL}$ of the prepared AMMO and SPENT supernatants. The supernatants were then incubated for $3 \mathrm{~h}$ at room temperature. After the incubation, chymotrypsin digestion was stopped by heating the mixture for $10 \mathrm{~min}$ at $80^{\circ} \mathrm{C}$. After cooling to room temperature, AMMO, and SPENT supernatants were used in the inhibition assay (Figure 1B).

\subsection{Analysis of Cell Densities}

Extrapolated cell densities of O157A grown in either AMMO or SPENT were examined for the difference in cell numbers between the two supernatants by subtracting the number of cells in the AMMO from the SPENT.

\subsection{Statistical Analysis}

Numerical OD data measured for each experiment were examined for normality and subsequently used for analyses. Time, treatment, control, and interactions were determined for all the experiments using a mixed linear model (Proc Mixed, SAS 9.4, SAS Institute Inc., Cary, NC, USA). $p$ values $<0.05$ 
were considered significant. Calculated standard deviations from each experiment are shown as bars within the Figures.

\section{Results}

\subsection{AMMO Isolation Protocol Confirmation}

Preliminary studies for both strains determined that OD measurement corresponded to plate counts in the provided growth curve in Section 2.2.1. OD based measurements were subsequently used to determine cell densities.

A comparison of OD measurements of O157A grown in a mixture of EC and AMMO to O157A grown in a mixture of EC and SPENT demonstrated that O157A inoculated into AMMO had significantly lower growth at 4,6 , and $8 \mathrm{~h}(p<0.05)$ (Figure 2B). Furthermore, the difference in cell density increased over time, and the E. coli O157A in SPENT had $-6 \times 10^{7} \mathrm{CFU} / \mathrm{mL}$ more cells than O157A in AMMO at $8 \mathrm{~h}$ (Figure 2A). In contrast, the OD of O103F grown in a mixture of EC and SPENT compared to O103F grown in a mixture of $\mathrm{EC}$ and $\mathrm{AMMO}$, demonstrated that the O103F cell proliferation was significantly greater $(p<0.05)$ in the presence of SPENT than in AMMO (Figure 2B). Concurrently, the difference in cell density demonstrated that O103F in SPENT had $-1.0 \times 10^{8} \mathrm{CFU} / \mathrm{mL}$ more O103F cells than O103F in AMMO at $8 \mathrm{~h}$ (Figure 2A). Furthermore, comparing the growth of O157A in SPENT to O103F in AMMO did not identify a significant difference in growth $(p>0.05)$. Expectedly, all controls of O103F or O157A in fresh EC grew to higher turbidity than O103F and O157A grown in SPENT (Figure 2B).

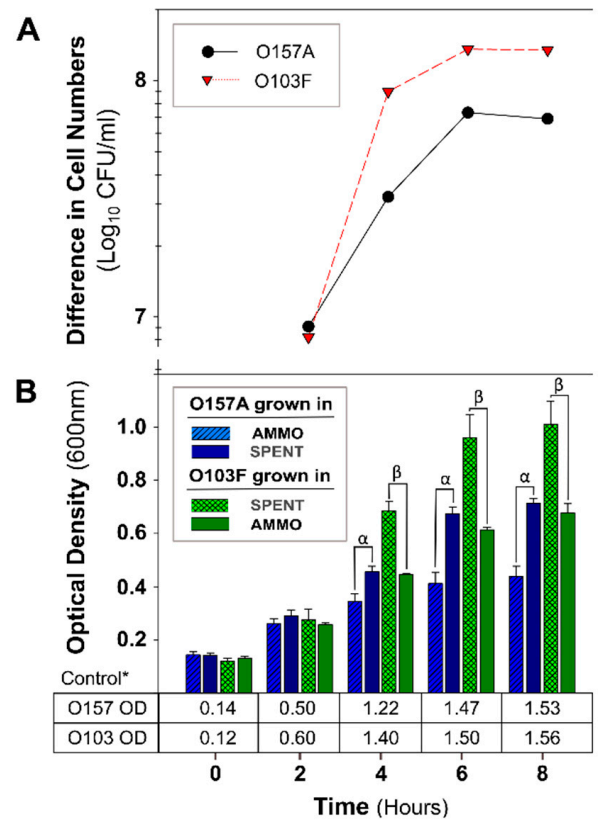

Figure 2. The molecule isolation protocol confirmation results for E. coli O157A grown in AMMO and SPENT in comparison to E. coli O103F grown in SPENT and AMMO. (A): The difference between the cell numbers for either O157A or O103F in the SPENT and in AMMO. (B): The OD $600 \mathrm{~nm}$ data for O157A in AMMO, O157A in SPENT, O103F in SPENT, and O103F in AMMO and * control in fresh EC as a numerical value below the bars. Symbols: $\alpha$ and $\beta$ denote a significant difference between growth in AMMO and SPENT for O157A and O103F, respectively $(p<0.05)$. A comparison of O103F growth in AMMO to O157A growth in SPENT revealed they are not significantly different. Note: (1) AMMO is the cell-free supernatant collected after $12 \mathrm{~h} \mathrm{E}$. coli O103F growth. SPENT is the cell-free supernatant collected after $12 \mathrm{~h}$ E. coli O157A growth. (2) Bars are the calculated standard deviation for AMMO and SPENT in each experiment (O157A and O103F) at each time point. 


\subsection{Investigation of AMMO Properties}

Preliminary studies revealed that between 8 and $24 \mathrm{~h}$, AMMO inhibition was diminishing and at $24 \mathrm{~h}$ no longer detectable (data not shown). Data are reported for the period up to $8 \mathrm{~h}$.

\subsubsection{The Effect of $\mathrm{pH}$, Autoclaving, Trypsin and Chymotrypsin Digestion}

The OD of O157A grown in a mixture of EC and AMMO after treatment ( $\mathrm{pH}$, Autoclaving, Trypsin, and Chymotrypsin) was not significantly different from O157A grown in EC with untreated AMMO (Figures 3B, 4B, 5B, and 6B). In contrast, a comparison of O157A grown in EC and AMMO (treated or untreated) to the O157A grown in EC and SPENT (treated or untreated) revealed significant inhibition of $\mathrm{O} 157$ growth at 4,6 , and $8 \mathrm{~h}(p<0.05)$. Additionally, the difference in cell density for treated or untreated AMMO and SPENT increased over time (Figures 3A, 4A, 5A and 6A) with the largest difference in cell density at $8 \mathrm{~h}$ (Table 1). The pure culture control of O157A in fresh EC grew to higher turbidity than O157A grown in SPENT in each experiment (Figures 3B, 4B, 5B, and 6B).

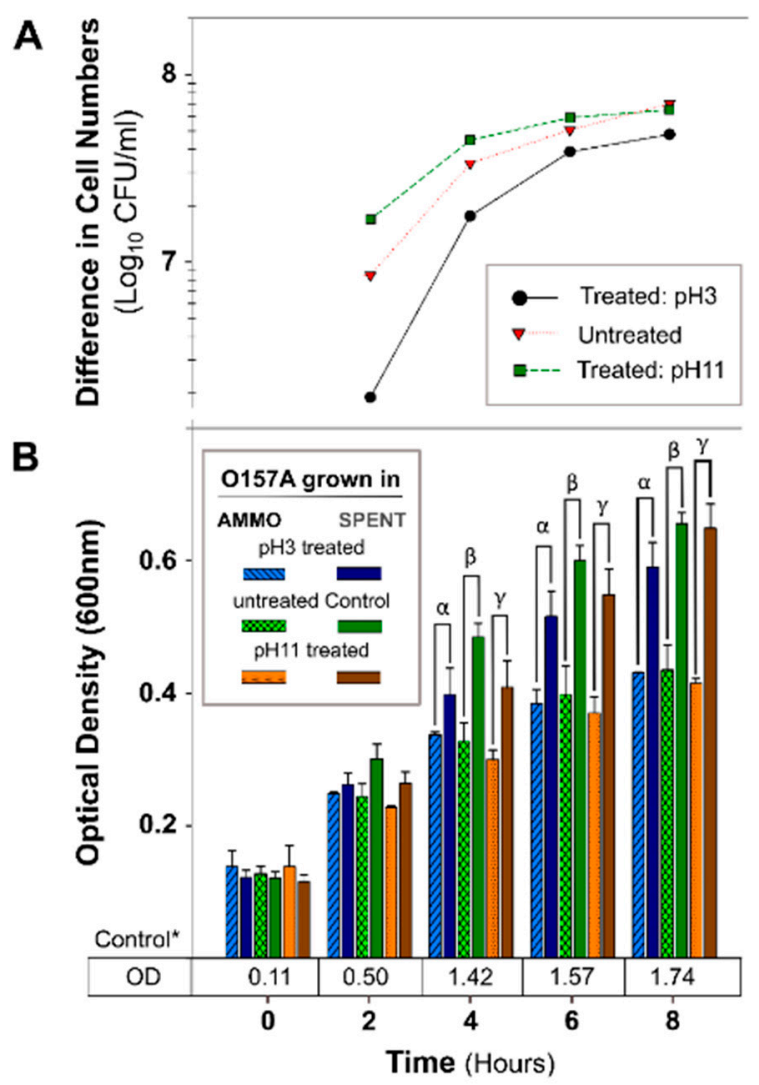

Figure 3. The effect of $\mathrm{pH}$ treated AMMO on growth inhibition of E. coli O157A at two pH's 3 and 11. (A): The difference between the cell numbers for O157A in SPENT and in AMMO at pH 3, pH 11, and untreated supernatant. (B): The $\mathrm{OD}_{600 \mathrm{~nm}}$ data for O157A grown in AMMO, in SPENT (pH 3, pH 11, and untreated) and ${ }^{*}$ control in fresh EC as a numerical value below the bars. Symbols: $\alpha, \beta$ and $\mathrm{y}$ denote a significant difference between O157A grown in AMMO and in the SPENT for $\mathrm{pH} 3$, untreated, and $\mathrm{pH} 11$ supernatants, respectively $(p<0.05)$. Note: $(\mathbf{1})$ AMMO is the cell-free supernatant collected after $12 \mathrm{~h}$ E. coli O103F growth. SPENT is the cell-free supernatant collected after $12 \mathrm{~h}$ E. coli O157A growth. (2) Bars are the calculated standard deviation for the treated or untreated AMMO and SPENT at each time point. 


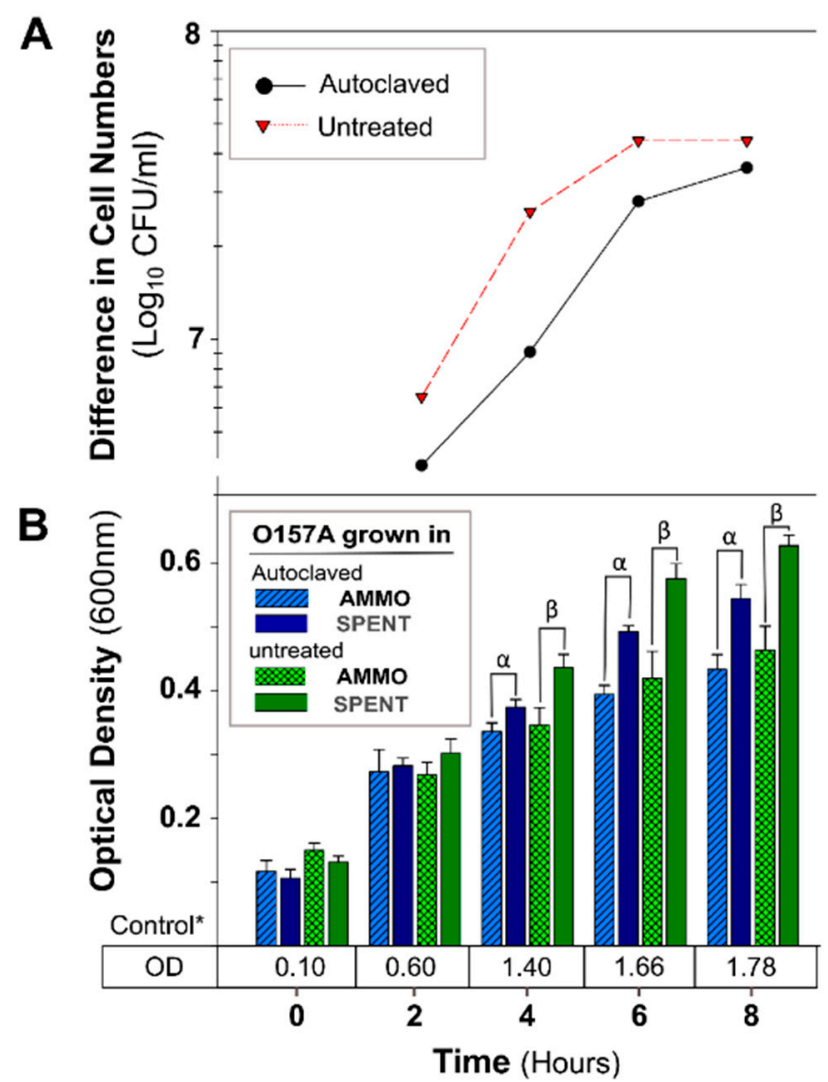

Figure 4. The effect of autoclaving AMMO on growth inhibition of E. coli O157A. (A): The difference between the cell numbers for O157A in SPENT and in AMMO with treated and untreated supernatant. (B): The $\mathrm{OD}_{600 \mathrm{~nm}}$ data for O157A grown in AMMO, in SPENT (treated and untreated), and * control in fresh EC as a numerical value below the bars. Symbols: $\alpha$ and $\beta$, denote a significant difference between O157A grown in AMMO and in SPENT for treated and untreated supernatants, respectively $(p$ $<0.05)$. Note: (1) AMMO is the cell-free supernatant collected after $12 \mathrm{~h} \mathrm{E}$. coli O103F growth. SPENT is the cell-free supernatant collected after $12 \mathrm{~h} \mathrm{E}$. coli O157A growth. (2) Bars are the calculated standard deviation for the treated or untreated AMMO and SPENT at each time point. 


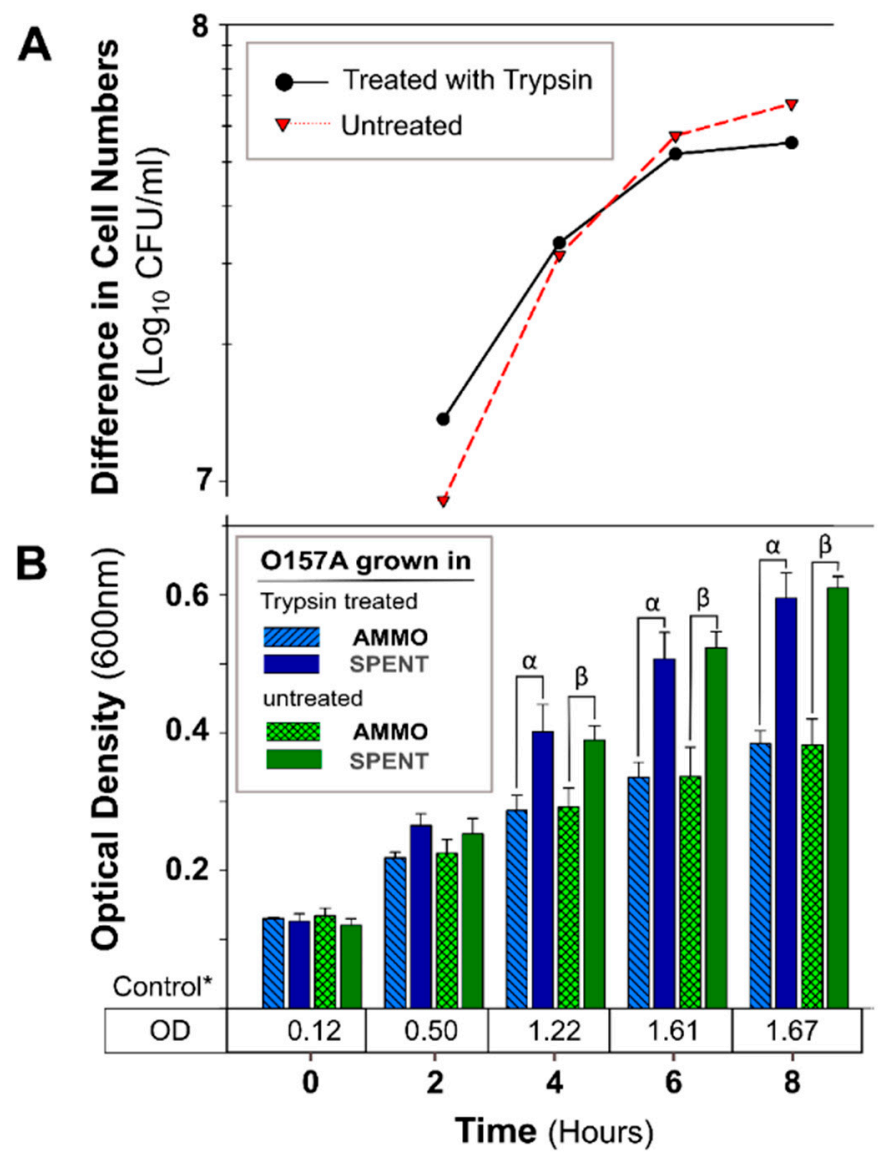

Figure 5. The effect of trypsin protease digestion of AMMO on growth inhibition of E. coli O157A over time. (A): The difference between the cell numbers for O157A in SPENT and in AMMO treated and untreated supernatant. (B): The $\mathrm{OD}_{600 \mathrm{~nm}}$ data for O157A grown in AMMO, in SPENT (treated and untreated), and * control in fresh EC as a numerical value below the bars. Symbols: $\alpha$ and $\beta$, denote a significant difference between O157A in AMMO and in SPENT for treated and untreated supernatants, respectively $(p<0.05)$. Note: $(\mathbf{1})$ AMMO is the cell-free supernatant collected after $12 \mathrm{~h} \mathrm{E}$. coli O103F growth. SPENT is the cell-free supernatant collected after $12 \mathrm{~h} \mathrm{E}$. coli O157A growth. (2) Bars are the calculated standard deviation for the treated or untreated AMMO and SPENT at each time point. 


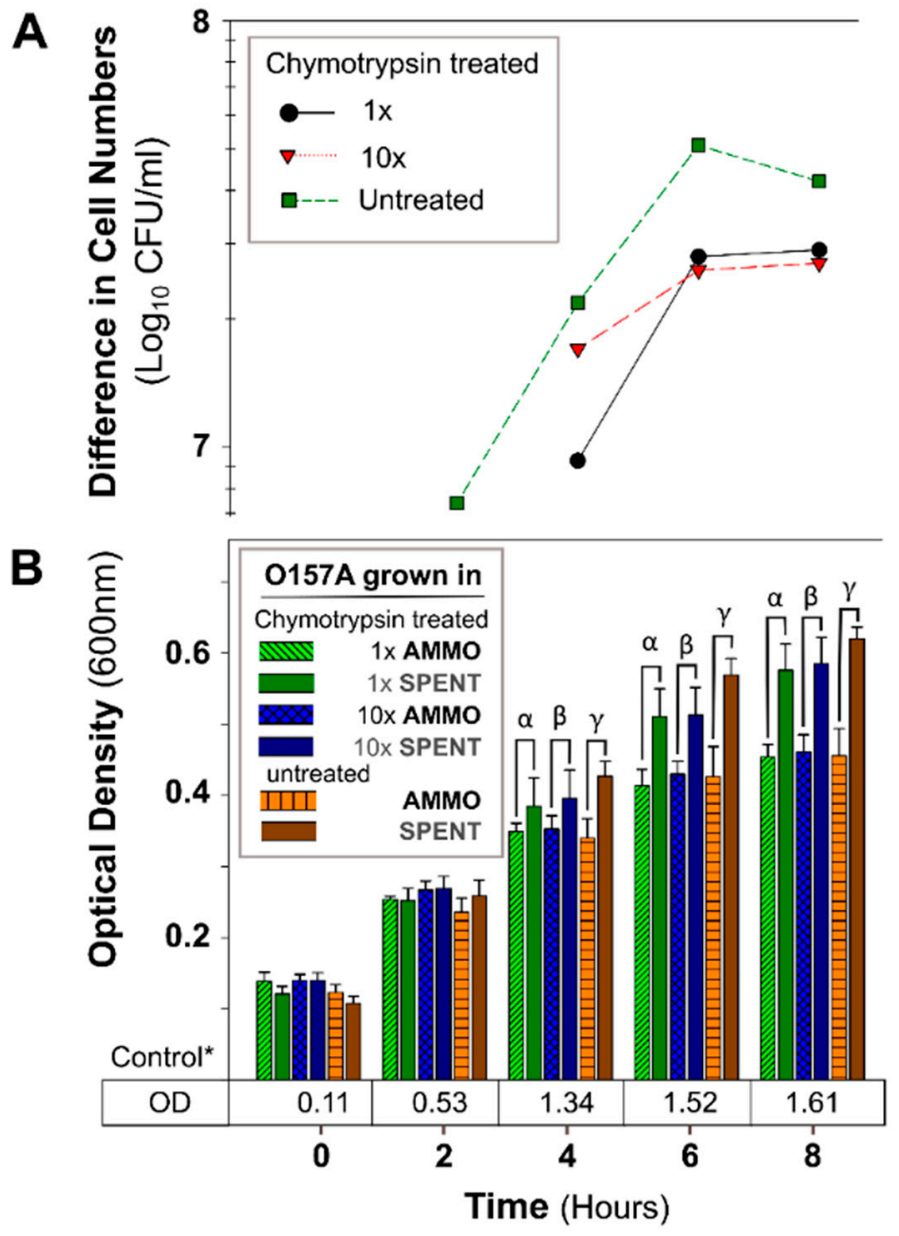

Figure 6. The effect of chymotrypsin protease digestion of AMMO on growth inhibition of E. coli O157A over time. (A): The difference between the cell numbers for O157A in SPENT and in AMMO with treated and untreated supernatants. (B): The $\mathrm{OD}_{600 \mathrm{~nm}}$ data for O157A grown in AMMO, in SPENT (treated and untreated), and * control in fresh EC as a numerical value below the bars. Symbols: $\alpha$, $\beta$ and $\gamma$, denote a significant difference between: O157A in AMMO and in SPENT for $1 \times, 10 \times$, and untreated supernatants, respectively $(p<0.05)$. Time-point $=2$ difference in cell number data not shown for chymotrypsin treated AMMO and SPENT $(1 \times$ and $10 \times)$ due to parallel OD $_{600 \mathrm{~nm}}$ data, and the difference is zero. Note: (1) AMMO is the cell-free supernatant collected after $12 \mathrm{~h} \mathrm{E.} \mathrm{coli} \mathrm{O103F}$ growth. SPENT is the cell-free supernatant collected after $12 \mathrm{~h} \mathrm{E}$. coli O157A growth. (2) Bars are the calculated standard deviation for the treated or untreated AMMO and SPENT at each time point.

Table 1. Difference in cell density between O157A grown in SPENT versus O157A grown in AMMO at $8 \mathrm{~h}$.

\begin{tabular}{|c|c|c|c|c|c|c|}
\hline \multirow[b]{2}{*}{ Treated } & \multicolumn{6}{|c|}{ Supernatant Trials (Cell Numbers in ${ }^{x} 10^{7}$ ) } \\
\hline & pH 3 & pH 11 & Autoclaved & Trypsin & C-Trypsin $1 x$ & C-Trypsin $10 x$ \\
\hline SPENT minus AMMO * & 5 & 6 & 3 & 5 & 3 & 3 \\
\hline Untreated Control & \multicolumn{2}{|c|}{$\mathrm{pH}$} & Autoclaved & Trypsin & \multicolumn{2}{|c|}{ Chymotrypsin } \\
\hline SPENT minus AMMO * & \multicolumn{2}{|c|}{6} & 4 & 6 & \multicolumn{2}{|c|}{4} \\
\hline $\begin{array}{l}\text { * Differences in cell density. } \\
\text { the supernatant and in each } \\
\text { in cell density is approxima } \\
\text { (2) AMMO is the cell-free st } \\
\text { collected after } 12 \mathrm{~h} \mathrm{E} \text {. coli } \mathrm{O}\end{array}$ & Note: & collected & $\begin{array}{l}\text { the } \mathrm{OD}_{600 \mathrm{~nm}} \text { of } \\
\text { O157A had sim } \\
\text { g previously ge } \\
\text { ter } 12 \text { h E. coli }\end{array}$ & $\begin{array}{l}\text { e } 12 \mathrm{~h} \mathrm{cu} \\
\text { ar growth } \\
\text { erated grc } \\
03 \mathrm{~F} \text { grow }\end{array}$ & $\begin{array}{l}\text { Ire was measurec } \\
\text { ensities at } 12 \mathrm{~h} \text {. } \\
\text { th curve numeri } \\
\text { SPENT is the ce }\end{array}$ & $\begin{array}{l}\text { prior to preparing } \\
\text { ote: (1) Difference } \\
\text { l data for O157A } \\
\text { l-free supernatant }\end{array}$ \\
\hline
\end{tabular}




\subsubsection{Comparison of Inhibition Activity}

The comparison of the average inhibition activity of AMMO across the different treatments at 4,6, and $8 \mathrm{~h}$ to untreated AMMO further revealed no effect of treatment on inhibition (Figure 7). Variability between the treated and untreated AMMO is minor, as demonstrated by the standard deviation, shown as bars on the graph.

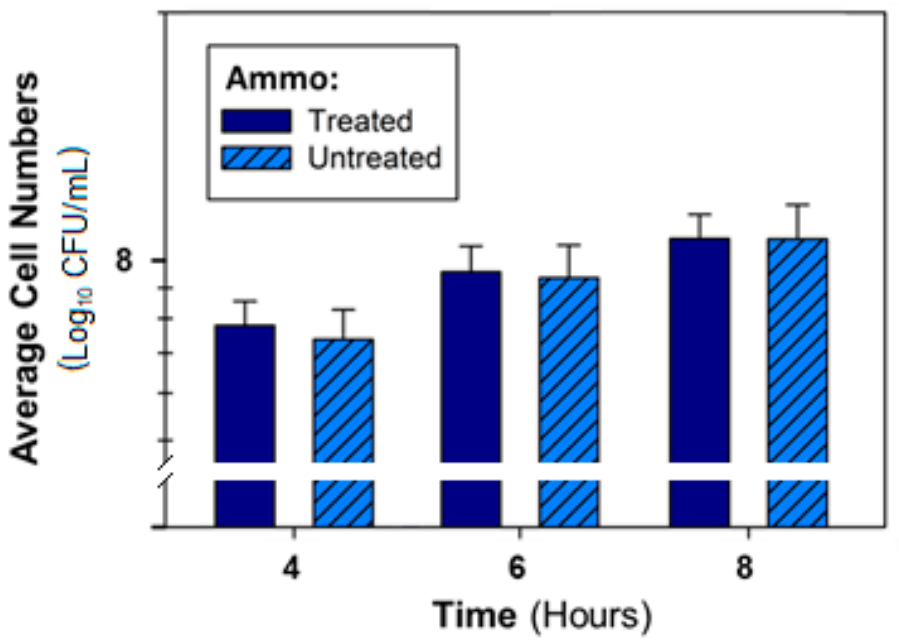

Figure 7. Comparison of average inhibition activity against E. coli $\mathrm{O} 157$ of treated AMMO across all treatments versus untreated AMMO (control) at time point 4, 6, and 8 h. Note: (1) Bars are the calculated standard deviation for the treated or untreated AMMO, respectively, at each time point. (2) $\mathrm{AMMO}$ is the cell-free supernatant collected after $12 \mathrm{~h} \mathrm{E}$. coli O103F growth.

\section{Discussion}

Interference competition is either contact-dependent or contact independent. Due to the removal of viable bacterial cells in our study, the inhibition of the competitor growth was solely based on contact-independent mechanisms. Contact independent inhibition occurs by one of the following known mechanisms-release of small molecules (less than $10 \mathrm{kDa}$ ), proteins (larger than $10 \mathrm{kDa}$ ), membrane vesicles, tailocins, and bacteriophages [28]. Across these mechanisms, a striking difference is the sensitivity of the active substances to physiochemical and biological treatments. Except for microcins, none of those known inhibitory agents are reported to persist the combination of extreme heat and pressure (autoclaving). In addition to heat resistance, microcins excreted by Gram-negative bacteria have been reported to be resistant to extreme $\mathrm{pH}$ and are resistant to proteolysis [29].

\subsection{AMMO Isolation Protocol Confirmation}

A previous study in our laboratory [26] revealed a competitive O103F champion producing strong diffusible molecule (AMMO), which inhibited the growth of a wide range of STEC isolates, including a STEC runner-up (O157A). Here we isolated and further investigated the AMMO, properties. The trials after isolation confirmed that O157A grown in AMMO was significantly inhibited compared to the O157A grown in SPENT $(p<0.05)$. Additionally, the cell density was greater in SPENT than in $\mathrm{AMMO}$ and the difference in cell density between them increased over time. Furthermore, our data are demonstrate that SPENT did not inhibit O103F growth, further confirming our previous results [26], and, in fact, O103F grown in SPENT had a higher cell density than O103F grown in AMMO. Feasibly, O103F has a metabolic advantage and is able to utilize nutrients not used by O157A as the metabolic pathways of different $E$. coli strains have been shown to vary in their ability to utilize different carbon sources [30]. Likely, O103F utilized a remaining nutrient source still present in SPENT. Comparison of O103F grown in AMMO to O157A grown in SPENT did not identify a significant difference in growth in the utilized media, providing evidence that the inhibition effect on O157A growth in AMMO is due 
to the presence of an antimicrobial compound(s) and not due to a lack of nutrients in the media. In addition, grown in fresh media, O157A and O103F had higher turbidity, demonstrating that inhibition (O157A) or no inhibition (O103F) was due to an external factor (AMMO synthesis) and not due to a strain fitness effect. In confirmation with our previous data, which demonstrated the production of a diffusible antimicrobial through an agarose barrier (no contact between competitors), the isolation of a diffusible and inhibitory AMMO occurred as E. coli has been reported to produce colicins and microcins targeting other E. coli and close relatives [13,31]. Furthermore, our results revealed that AMMO is effective in the absence of live bacterial cells, which may alleviate regulatory hurdles probiotic bacteria encounter when being considered as a drug to treat human disease [32]. In accordance with previous studies, AMMO inhibited the STEC O157A, and similar effects have been reported for the microcin producing probiotic E. coli Nissle, which displaced pathogens from an inflamed gut [19] or reduced the number of STEC O157:H7 and O104:H4 in vitro [33].

Colicin and microcin producers target various systems in their prey and kill them using several mechanisms from forming cell wall channels to the corruption of the intracellular machinery but are themselves resistant to this activity [34,35]. Production of either microcins or colicins is always coupled with resistance genes and antidote synthesis. O157A succumbs to at least one AMMO produced by O103F, suggesting a lack of resistance. In contrast and in accordance with our previous results [26], $\mathrm{O} 103 \mathrm{~F}$ is not inhibited by any antimicrobial produced by O157A, suggesting O103F is resistant to any antimicrobials produced by O157A. Resistance to colicins and microcins can occur through the production of these antimicrobials since production is always paired with the synthesis of resistance proteins or through mutations in receptors or uptake mechanisms for the bacteriocin [34]. E. coli has been shown to produce more than one colicin and microcin [36]. Plasmids encoding bacteriocins are stably maintained in microbial populations, most likely due to the lethal disadvantage of lost resistance [4]. Here, O103F may either have resistance to any O157A antimicrobial because it can produce the antimicrobial or has mutations in the receptors for the O157A antimicrobial as previous research revealed that $E$. coli could acquire resistance to bacteriocins in competition assays [37].

\subsection{Investigation of AMMO Properties}

The results across all trials revealed that AMMO was not affected by any of the treatments. Neither $\mathrm{pH}$, heat (pressure) nor protease digestion affected the inhibitory properties of AMMO. In an applied scenario, the stability of the molecule would offer a wide range of technical treatment options for the implementation of purifications within an industrial-scale setting.

In each trial, there were no significant differences in O157A growth between treated and untreated AMMO, and comparison of the inhibition activity of only the treated AMMO revealed a similar inhibition pattern across all treatments, further demonstrating that treatment had no effect. Additionally, O157A growth was significantly inhibited $(p<0.05)$ when grown in the presence of AMMO compared to SPENT, regardless of treatment, showing treatment did not affect the ability of AMMO to inhibit O157A growth. Concurrently, this effect was further demonstrated when examining cell numbers of O157A, which were more numerous in treated or untreated SPENT compared to treated or untreated AMMO in each experiment. Additionally, pure culture controls of O157A grew to higher cell numbers compared to O157A grown in SPENT, demonstrating that the inhibitory effect was due to the presence of AMMO and not due to any variation of viability. The evidence of physicochemical and enzymatic resistant characteristics of AMMO suggests that at least one microcin is produced by O103F.

Microcins are small antimicrobial peptides and have been mainly discovered in E. coli (one in Klebsiella) with a molecular weight of less than $10 \mathrm{kDa}$ [38]. Microcins have a narrow killing range, primarily targeting E. coli and their close relatives. Remarkably, despite being these "killing machines", the mode of action of many microcins is unknown, including microcin $\mathrm{M}$, one of the microcins produced by E. coli Nissle, a probiotic that has been used for over 100 years to mitigate intestinal pathogens [29]. Microcin properties of extreme $\mathrm{pH}$, protease, and heat resistance [39], are commonly shared with bacteriocins from lactic acid bacteria, $[13,38]$. Resistance to extreme $\mathrm{pH}$ or proteases varies among 
microcins. Microcin E492 is resistant to low $\mathrm{pH}$ [40], while J25 is resistant to both low and high $\mathrm{pH}$ extremes [41]. Others are resistant to the protease trypsin but not to chymotrypsin digestion, vice versa or resistant to both [40]. Heat resistance is shared among microcins [40], and microcin J25 has been shown to resist autoclaving $\left(15 \mathrm{~min}\right.$ at $121^{\circ} \mathrm{C}$ ) [41]. The AMMO produced by O103F has analogous characteristics, and plausibly is a molecule of similar design. Furthermore, our data demonstrated that the AMMO effect was no longer detectable after $24 \mathrm{~h}$, an indicator for a "single-use" effect. Microcin $\mathrm{C}$ enters the host cells by mimicking nutrient properties and after cell uptake is cleaved by the host intracellular machinery to create the active compound [39]. Plausibly, this cleavage of microcin $C$ is irreversible, and AMMO undergoes a similar transformation.

Aside from those properties discussed above, microcins can be further differentiated from colicins because they are not induced by the bacterial SOS (response to DNA damage) system, and secreted microcins are not lethal to the producing cells [34]. To date, 14 microcins have been identified [12], but only eight have been structurally characterized [29]. Some microcins, such as H47 and I47 or C7 and C51, have similar microcin gene clusters and only differ by 3 or 1 additional genes, respectively [15]. Ultimately, AMMO produced by O103F appears to be a microcin with a change in the microcin gene cluster for an enhanced killing potential. Research comparing the microcin gene cluster of O103F with sequences of known microcins may elucidate such a probability.

The production of microcins by E. coli [13] is a tactic used to out-compete their adversaries [4]. Microcins are deemed a potential replacement for antibiotics to mitigate pathogens both in human medicine and in the farm-to-fork continuum [16]. Antibiotic resistance is a global challenge evoked by their overuse in the livestock industry and human medicine, which led to the emergence of resistant pathogens. Contrary to traditional broadband antibiotics, microcins have a narrow, species-specific killing range $[10,16]$. Since his discovery about 100 years ago in the battlefields of WWI, the E. coli Nissle strain has been effectively used to treat human intestinal infections, and the specific Nissle microcins are considered the active antimicrobial substance [17,19].

As a foodborne pathogen, STEC causes severe intestinal infections in humans [20,42], and effective mitigation strategies are lacking [22-24]. Use of probiotic bacteria that can out-compete STEC is being considered as an approach to eliminate this pathogen, and colicin producers isolated from sheep fecal samples have been shown to inhibit STEC O157:H7 growth [25].

A previous study in our laboratory showed a diverse STEC growth inhibition by AMMO produced by $\mathrm{O} 103 \mathrm{~F}$ [26], and the results from this study strongly suggest that O103F produces at least one very effective microcin. Microcins are considered part of the killing repertoire of the probiotic E. coli Nissle strain. The type of microcins produced by E. coli O103F holds the potential to be used as a STEC mitigation strategy. In logical stepwise approaches, we aim to evaluate this molecule further and gain more knowledge on the antimicrobial properties produced by O103F. Future studies examining the genome and plasmid sequences of O103F for microcins, the biochemical structure of AMMO and physiological properties, including metabolic pathways, are required to elucidate the therapeutic potential of this strain and the antimicrobial it produces.

\section{Conclusions}

Agriculture, as an evolutionary Big Bang, triggered a new microbial multiverse and changed the dynamics of human and microbe (pathogen) interactions. Most recent global transformation, including biological technologies (and the use of antimicrobial substances) have fundamentally altered the way, size, speed, and scope of how we produce and consume food, but in addition, promoted the emergence of virulent microbes with resistance to antibiotics. Microcin molecules are regarded as a potential alternative to antibiotics. Therapeutic microcin properties may warrant the use as a next-generation control strategy in livestock production systems or to mitigate pathogens after human infections. Ultimately, the microcin we tested here inhibited the growth of E. coli pathogens after a range of physicochemical and enzymatic inactivation treatments. The antimicrobial properties suggest that this type of isolated molecule could be an antibiotic candidate even in the absence of the viable E. coli 
producer. The resistance to treatments that make the molecule an ideal candidate for industrial-scale isolation and purification technologies.

Author Contributions: Conceptualization, S.-J.P. and T.R.; Data curation, S.-J.P.; Formal analysis, S.-J.P.; Investigation, S.-J.P. and T.R.; Methodology, S.-J.P. and T.R.; Project administration, T.R. Resources, T.R.; Supervision, T.R.; Writing—original draft, S.-J.P.; Writing—review \& editing, T.R. All authors have read and agreed to the published version of the manuscript.

Funding: This research received no external funding.

Acknowledgments: We acknowledge and thank Susanne Trapp and Yidong Graham for assistance in the laboratory and Rahat Zaheer, Andrew Cameron, James Thomas, and Kim Stanford for their willingness to share their expertise and knowledgeable discussions. Lastly but not least, Shaun Cook for his critical review, sharing his expertise and invaluable suggestions.

Conflicts of Interest: The authors declare no conflict of interest.

\section{References}

1. Dethlefsen, L.; McFall-Ngai, M.; Relman, D.A. An ecological and evolutionary perspective on human-microbe mutualism and disease. Nature 2007, 449, 811-818. [CrossRef]

2. Wolfe, N.D.; Dunavan, C.P.; Diamond, J. Origins of major human infectious diseases. Nature 2007, 447, 279-283. [CrossRef]

3. Gonzalez, D.; Sabnis, A.; Foster, K.R.; Mavridou, D.A.I. Costs and benefits of provocation in bacterial warfare. Proc. Natl. Acad. Sci. USA 2018, 115, 7593-7598. [CrossRef]

4. Inglis, R.F.; Bayramoglu, B.; Gillor, O.; Ackermann, M. The role of bacteriocins as selfish genetic elements. Biol. Lett. 2013, 9, 20121173. [CrossRef] [PubMed]

5. García-Bayona, L.; Comstock, L.E. Bacterial antagonism in host-associated microbial communities. Science 2018, 361, eaat2456. [CrossRef] [PubMed]

6. Darwin, C.R. The Variation of Animals and Plants under Domestication, 1st ed.; William Clowes and Sons Press: London, UK, 1868; pp. 414-443.

7. Stubbendieck, R.M.; Straight, P.D. Multifaceted interfaces of bacterial competition. J. Bacteriol. 2016, 198, 2145-2155. [CrossRef] [PubMed]

8. Garcia, E.C. Contact-dependent interbacterial toxins deliver a message. Curr. Opin. Microbiol. 2018, 42, 40-46. [CrossRef] [PubMed]

9. Engevik, M.A.; Versalovic, J. Biochemical features of beneficial microbes: Foundations for therapeutic microbiology. Microbiol. Spectrum 2017, 5. [CrossRef] [PubMed]

10. Kleanthous, C. Swimming against the tide: Progress and challenges in our understanding of colicin translocation. Nat. Rev. Microbiol. 2010, 8, 843-848. [CrossRef]

11. Naimi, S.; Zirah, S.; Hammami, R.; Fernandez, B.; Rebuffat, S.; Fliss, I. Fate and biological activity of the antimicrobial lasso peptide microcin J25 under gastrointestinal tract conditions. Front. Microbiol. 2018, 9. [CrossRef]

12. Rebuffat, S. Microcins and other bacteriocins: Bridging the gaps between killing strategies, ecology and applications. In The Bacteriocins: Current Knowledge and Future Prospects; Dorit, R.L., Roy, S.M., Riley, M.A., Eds.; Caister Academic Press: Norfolk, UK, 2016; pp. 11-34.

13. Duquesne, S.; Petit, V.; Peduzzi, J.; Rebuffat, S. Structural and functional diversity of microcins, gene-encoded antibacterial peptides from enterobacteria. J. Mol. Microbiol. Biotechnol. 2007, 13, 200-209. [CrossRef] [PubMed]

14. Chavan, M.A.; Riley, M.A. Molecular evolution of bacteriocins in gram-negative bacteria. In Bacteriocins: Ecology and Evolution; Springer: Berlin, Germany, 2007; pp. 19-43.

15. Duquesne, S.; Destoumieux-Garzon, D.; Peduzzi, J.; Rebuffat, S. Microcins, gene-encoded antibacterial peptides from Enterobacteria. ChemInform 2007, 38. [CrossRef]

16. Gillor, O.; Etzion, A.; Riley, M.A. The dual role of bacteriocins as anti- and probiotics. Appl. Microbiol. Biotechnol. 2008, 81, 591-606. [CrossRef] [PubMed]

17. Sonnenborn, U. Escherichia coli strain Nissle 1917-from bench to bedside and back: History of a special Escherichia coli strain with probiotic properties. FEMS Microbiol. Lett. 2016, 363. [CrossRef] [PubMed] 
18. Deriu, E.; Liu, J.Z.; Pezeshki, M.; Edwards, R.A.; Ochoa, R.J.; Contreras, H.; Libby, S.J.; Fang, F.C.; Raffatellu, M. Probiotic bacteria reduce Salmonella typhimurium intestinal colonization by competing for iron. Cell Host Microbe 2013, 14, 26-37. [CrossRef] [PubMed]

19. Sassone-Corsi, M.; Nuccio, S.P.; Liu, H.; Hernandez, D.; Vu, C.T.; Takahashi, A.A.; Edwards, R.A.; Raffatellu, M. Microcins mediate competition among Enterobacteriaceae in the inflamed gut. Nature 2016, 540, 2802-2830. [CrossRef]

20. Rahal, E.A.; Fadlallah, S.M.; Nassar, F.J.; Kazzi, N.; Matar, G.M. Approaches to treatment of emerging Shiga toxin-producing Escherichia coli infections highlighting the O104:H4 serotype. Front. Cell. Infect. Microbiol. 2015, 5, 24. [CrossRef]

21. Cleary, T.G. The role of Shiga-toxin-producing Escherichia coli in hemorrhagic colitis and hemolytic uremic syndrome. Semin. Pediatr. Infect. Dis. 2004, 15, 260-265. [CrossRef]

22. Stanford, K.; Hannon, S.; Booker, C.W.; Jim, G.K. Variable efficacy of a vaccine and direct-fed microbial for controlling Escherichia coli O157:H7 in feces and on hides of feedlot cattle. Foodborne Pathog. Dis. 2014, 11, 379-387. [CrossRef]

23. Stephens, T.P.; Stanford, K.; Rode, L.M.; Booker, C.W.; Vogstad, A.R.; Schunicht, O.C.; Jim, G.K.; Wildman, B.K.; Perrett, T.; McAllister, T.A. Effect of a direct-fed microbial on animal performance, carcass characteristics and the shedding of Escherichia coli O157 by feedlot cattle. Anim. Feed Sci. Technol. 2010, 158, 65-72. [CrossRef]

24. Jin, L.; Wang, Y.; Iwaasa, A.D.; Li, Y.; Xu, Z.; Schellenberg, M.P.; Liu, X.L. Purple Prairie Clover (Dalea purpurea Vent) reduces fecal shedding of Escherichia coli in pastured cattle. J. Food Prot. 2015, 78, 1434-1441. [CrossRef] [PubMed]

25. Askari, N.; Ghanbarpour, R. Molecular investigation of the colicinogenic Escherichia coli strains that are capable of inhibiting E. coli O157:H7 in vitro. BMC Vet. Res. 2019, 15, 14. [CrossRef] [PubMed]

26. Paquette, S.-J.; Zaheer, R.; Stanford, K.; Thomas, J.; Reuter, T. Competition among Escherichia coli Strains for Space and Resources. Vet. Sci. 2018, 5, 93. [CrossRef]

27. Kulp, A.; Kuehn, M.J. Biological functions and biogenesis of secreted bacterial outer membrane vesicles. Annu. Rev. Microbiol. 2010, 64, 163-184. [CrossRef] [PubMed]

28. Granato, E.T.; Meiller-Legrand, T.A.; Foster, K.R. The evolution and ecology of bacterial warfare. Curr. Biol. 2019, 29, R521-R537. [CrossRef] [PubMed]

29. Baquero, F.; Lanza, V.F.; Baquero, M.-R.; del Campo, R.; Bravo-Vazquez, D.A. Microcins in Enterobacteriaceae: Peptide antimicrobials in the eco-active intestinal chemosphere. Front. Microb. 2019, 10. [CrossRef]

30. Paquette, S.-J. Control of Substrate Utilization by O-islands and S-loops in Escherichia Coli O157:H7. Master's Thesis, University of Lethbridge, Lethbridge, AB, Canada, 2011.

31. Cascales, E.; Buchanan, S.K.; Duché, D.; Kleanthous, C.; Lloubes, R.; Postle, K.; Riley, M.; Slatin, S.; Cavard, D. Colicin biology. Microbiol. Mol. Biol. Rev. 2007, 71, 158-229. [CrossRef]

32. Quigley, E.M.M. Prebiotics and probiotics in digestive health. Clin. Gastroenterol. Hepatol. 2019, 17, 333-344. [CrossRef]

33. Mohsin, M.; Guenther, S.; Schierack, P.; Tedin, K.; Wieler, L.H. Probiotic Escherichia coli Nissle 1917 reduces growth, Shiga toxin expression, release and thus cytotoxicity of enterohemorrhagic Escherichia coli. Int. J. Med. Microbiol. 2015, 305, 20-26. [CrossRef]

34. Gillor, O.; Kirkup, B.C.; Riley, M.A. Colicins and microcins: The next generation antimicrobials. In Advances in Applied Microbiology; Academic Press: Waltham, MA, USA, 2004; pp. 129-146.

35. Braun, V.; Patzer, S.I.; Hantke, K. Ton-dependent colicins and microcins: Modular design and evolution. Biochimie 2002, 84, 365-380. [CrossRef]

36. Budič, M.; Rijavec, M.; Petkovšek, Ž.; Žgur-Bertok, D. Escherichia coli bacteriocins: Antimicrobial efficacy and prevalence among isolates from patients with bacteraemia. PLoS ONE 2011, 6, e28769. [CrossRef] [PubMed]

37. Khare, A.; Tavazoie, S. Multifactorial competition and resistance in a two-species bacterial system. PLoS Genet. 2015, 11, e1005715. [CrossRef] [PubMed]

38. Pons, A.M.; Lanneluc, I.; Cottenceau, G.; Sable, S. New developments in non-post translationally modified microcins. Biochimie 2002, 84, 531-537. [CrossRef]

39. Rebuffat, S. Microcins in action: Amazing defence strategies of Enterobacteria. Biochem. Soc. Trans. 2012, 40, 1456-1462. [CrossRef] [PubMed]

40. Baquero, F.; Moreno, F. The microcins. FEMS Microbiol. Lett. 1984, 23, 117-124. [CrossRef] 
41. Salomón, R.A.; Farías, R.N. Microcin 25, a novel antimicrobial peptide produced by Escherichia coli. J. Bacteriol. 1992, 174, 7428-7435. [CrossRef]

42. Smith, J.L.; Fratamico, P.M.; Gunther, N.W. Chapter Three-Shiga Toxin-Producing Escherichia coli. In Advances in Applied Microbiology; Academic Press: Waltham, MA, USA, 2014; pp. 145-197.

(C) 2019 by the authors. Licensee MDPI, Basel, Switzerland. This article is an open access article distributed under the terms and conditions of the Creative Commons Attribution (CC BY) license (http://creativecommons.org/licenses/by/4.0/). 